\title{
INTELLECTUAL CAPITAL BASED MANAGEMENT CONTROL SYSTEMS
}

\author{
Lidia Galabova', Mina Daskalova ${ }^{2}$ \\ Department of Economics, Industrial Engineering and Management, Faculty of Management, \\ Technical University of Sofia, 8 Klimnt Ohridski Blvd., Sofia, Bulgaria \\ E-mails: 'lgalabova@tu-sofia.bg (corresponding author); ${ }^{2}$ minadaskalova@tu-sofia.bg
}

Received 04 March 2020; accepted 04 May 2020

\begin{abstract}
Management control systems (MCS) are formal, information-based routines and procedures (Simon, 1995) applied in strategic management practice. They are developed to help management balance the tension between organisational strategy and human behaviour. However, recent studies (Galabova, 2011, 2014) have shown that along with tangible, intangible assets impact on organisational performance. The aim of the paper is to propose a theoretical framework on how intangibles, and more specifically intellectual capital elements: human, structural and relational capital can be embedded as a part of a contemporary management control system. To examine these, we present a literature review together with data from former empirical studies. The paper will present a conceptual model on how human, structural and organisational capital could be monitored and controlled as an important part of MCSs.
\end{abstract}

Keywords: management control systems, strategy, intellectual capital, performance, personnel.

JEL Classification: L20, M10.

\section{Introduction}

It is generally accepted that management control is an important part of strategic management and organisational performance (Bedford et al., 2016; Langfield-Smith, 1997; Otley et al., 1995; Simon, 1995), which applies a wide variety of tools to monitor, collect information, process, communicate and advise actions in compliance with the strategy of the firm. Until recently most of the firm management and strategy development theories have been based on the study, measurement, evaluation and search for optimal solutions for increasing profit as a result of physical and financial capital exploitation. Thus management control was predominantly focused on financial information - monitoring financial flows on the one hand, and on the other hand, measuring various aspects of the company's performance - using financial evaluation as an unified measure.

Management control literature and practice have evolved over the years to acknowledge that despite the initially commonly spread accounting-based framework (Anthony, 1965) management control needs a much wider perspective (Langfield-Smith, 1997; Berry et al., 2009). In their indepth historical research Otley et al. (1995) single out Lowe and Mary Parker Follet (described by Parker, 1986) as scholars considering management control from a broader perspective. While Lowe (1971) focused on the need for the firm to adapt to changes which require that "the work behaviour of its employees is measured by reference to a set of operational sub-goals (which confront with overall objectives) so that the discrepancy between the two can be reconciled and corrected for", Follet believes that management should control not single elements, but complex interrelationships. Her stance was that control should be based on self-regulating, self-directing individuals and groups who recognised common interests and objectives.

Drawing upon these earlier ideas Otley et al. (1995) came to the conclusion that the practice of researching management control needs to recognise the environment in which the firms exist and to loosen the boundaries around the area of concern. Gradually, the range of what is included in management control is being extended. One of the factors impacting on the business environment is the transition to a knowledge-based economy, which makes the impact of intangibles on the value creation process much more visible. For the sake of clarity, it needs to be mentioned that intangibles are all those things that: have an impact on the company's performance; are a potential source of future benefits, but do not have a physical embodiment.

Recognising these changes management control took on board a range of non-financial performance indicators treated in Simons' Levers of Control (1995), along with new reporting frameworks, 
such as the Balanced Scorecard of Kaplan and Norton (1992), where non-financial measures (e.g. customer operations and innovation perspectives) are placed alongside traditional financial measures, thus acknowledging the impact of intangibles and intellectual capital (Johanson et al., 2007).

However, while the intangibles and the intellectual capital have been explored as factors of strategic importance, impacting on the firm's performance, little research has been focused on studying how they can be embedded as part of management control systems.

This paper aims to explore how intellectual capital is interrelated with management control system and how its elements can become (or be embedded as) an integral part of it.

\section{Methodology}

The research method applied is an extensive review of management control and Intellectual Capital (IC) literature, and in-depth comparative analysis of Management Control Systems (MCS) frameworks and IC concepts.

The paper investigates former empirical studies of the application of some of the more widely spread and applied MCS. Further, it analyses the structure and the constituent elements of these management control systems from the perspective of intellectual capital looking for crossing points. Drawing upon management control and intellectual capital literature the authors focus the attention on some specific characteristics of IC relevant to the MCS in the conditions of knowledge-based economy.

Aimed at exploring how constituent elements of IC can be applied in order to improve and develop management control systems, the paper focuses on two of the more popular among scholars and practitioners MCSs, namely Simons' Levers of Control (1995) and Balanced Scorecard (Kaplan \& Norton, 1992).

Drawing upon MCS and IC literature analysis an IC-based management control perspective is proposed. IC is seen as a dynamic interaction between its three core elements: human, relational and structural capital. We argue that MCSs are related to some of the IC core elements and their frameworks can be substantially improved as a result of embedding these elements as part of them.

Finally, the requirements to a sustainable strategy management in a knowledge-based economy are reconsidered. The need for both tangible and intangible parameters to be monitored is justified.

\section{Strategy, intellectual capital and management control systems}

Modern Knowledge-based Economy imposes new requirements for strategy management, leading to the development of new perspectives for value creation and sustainable competitive advantage. Gradually intangibles and more specifically Intellectual Capital are recognized as essential to successful strategies.

From a broader strategic perspective management control systems can be regarded as systems transmitting useful information to support managers in the decision making process, leading to the achievement of company goals in an efficient and effective manner (Anthony \& Govindarajan, 2007). This broad definition supports the paper argument as it considers not only formal, but also informal information-based routines and procedures. Thus it makes it possible to outline the fields where MCS and Intellectual Capital have crossing points, and IC elements can be applied as part of the MCS performance indicators. Further, it provides a useful framework enabling the development of a theoretical model describing how the main components of IC are interrelated with MCS and contribute to achieving the strategic goals of the firm.

\subsection{Intangibles and Intellectual Capital}

Intangibles are value-creating components that derive from people. They are created as a result of the interaction among competence, internal structure and external structure (Sveiby, 1997).

"Some assets - like brand names, customer relationships, and the competence of employees - are best seen as knowledge structures, that is, intangible assets."

By its nature Intellectual Capital is a collection of intangibles (Sudarsanam et al., 2006, p. 291; Claver-Cortez et al., 2007, p. 172; Galabova \& Ahonen, 2011). However, this is far too broad a description for the purposes of the present paper. For the sake of clarity and precision we need to provide a more detailed definition. IC is a complex, dynamically changing driver of value creation through the constant interaction and transformation of its three key elements - human capital, structural capital and relational capital:

- human capital (HC) - constituent individual competence, personal attitude, skills, knowledge (explicit and tacit), experience, personal networks, commitment and motivation, health (physical and mental), work well-being, etc. 
- structural capital (SC) - constituent organisational structures; organisational culture; recognition, evaluation and appraisal systems; intellectual property; management systems, information and the like;

- relational capital $(R C)$ - describing the impact of brand, image, social reputation, all relationships that the organisation has with different stakeholders (e.g. clients, suppliers, partners, owners, lenders, trade unions, financial institutions, etc.) (Galabova \& Ahonen, 2011).

It is the authors' conviction that through its specific components the IC can be embedded into the design of MCS.

Drawing upon Berry et al. (2009) review of management control models for performance measurement and management the paper considers how IC elements could be included to provide additional information in support to strategy implementation.

\subsection{Simons' Levers of Control}

In his seminal work Levers of Control, Simon (1995) considers the control of business strategy from four perspectives:

- Belief systems - related to core values. These systems are meant to inspire and direct search for new opportunities.

- Boundary systems - outlining risks to be avoided. These systems set limits to opportunity seeking behaviour.

- Diagnostic control systems - based on critical performance variables. The role of these systems is to motivate, monitor and reward achievement of specified goals.

- Interactive control systems - considering strategic uncertainties. These systems are meant to stimulate organisational learning and emergence of new ideas and strategies.

One of the sustainable critiques of Simons' levers of control is that although they include informal controls the conceptualisation of the belief system does not include important formal controls such as group norms, socialisation and culture (Collier, 2005). However, comparing Simons' levers of control and IC capital core elements we can easily notice that Belief system can be related to structural capital and more specifically to one of its constituent elements - organisational culture.

Organisational cultures are tightly linked to the deeply held values, beliefs, attitudes and assumptions in the firms. In essence they are the result of processes that arise from dynamic interaction among individuals or members of a social system. Thus we can consider a firm's organisational culture as the visible part of its belief system.

It seems that most adaptable to further development and upgrade are the Diagnostic control systems (DCS) which can be improved to provide both formal and informal control. The formal control is provided via all finance control systems. It is authors belief that IC is an excellent framework to provide informal control, as it takes into consideration all elements not included in the finance control systems, but worth to be monitored as part of management control. The critical performance variables of the diagnostic system can include most elements of IC (Table 1). This means that diagnostic systems used at present can be developed further and can be designed to monitor both tangible and intangible assets and results.

Table 1. IC-based performance indicators of DCS (source: authors)

\begin{tabular}{|l|l|l|}
\hline \multicolumn{3}{|c|}{ Diagnostics Control Systems } \\
\hline Human Capital & \multicolumn{1}{|c|}{$\begin{array}{c}\text { Structural } \\
\text { Capital }\end{array}$} & \multicolumn{1}{|c|}{$\begin{array}{c}\text { Relational } \\
\text { Capital }\end{array}$} \\
\hline Competence & $\begin{array}{l}\text { Evaluation and } \\
\text { appraisal } \\
\text { system }\end{array}$ & $\begin{array}{l}\text { Reputation and } \\
\text { image of the } \\
\text { firm }\end{array}$ \\
\hline Knowledge & $\begin{array}{l}\text { Quality manage- } \\
\text { ment system }\end{array}$ & \\
\hline Skills & $\begin{array}{l}\text { Organisation } \\
\text { management } \\
\text { system }\end{array}$ & \\
\hline Health & $\begin{array}{l}\text { Information } \\
\text { management } \\
\text { systems }\end{array}$ & \\
\hline
\end{tabular}

As far as Interactive control systems are designed to foster organisational learning and innovativeness they can be considered as closely related to IC in general. However, taking a closer look authors come to the conclusion that various elements of relational capital can be applied to support these systems in providing useful and reliable information.

IC-based Interactive Control System could consider monitoring and evaluation of the following performance indicators:

- Relationships with customers;

- Relationships with suppliers;

- Relationships with competitors;

- Relationships with financial institutions;

- Relationships with professional organisations;

- Relationships with trade unions. 
Although at first sight it might seem that intangibles and IC are irrelevant as far as Boundary systems are concerned, on a closer look there is an important aspect, which is worth considering. According to Simon, Boundary system provides freedom of thought, new ideas generation and discovery of new opportunities for value creation as it sets the limits of what is to be avoided. Drawing upon this the authors suggest considering the dual nature of intangibles - that means consider the fact that they might have a positive and a negative impact. Let us take for example the image of a firm.

Table 2. Simons' Levers of Control IC-based performance indicators (source: authors)

\begin{tabular}{|c|c|c|c|}
\hline \multirow{2}{*}{$\begin{array}{c}\text { Manage- } \\
\text { ment } \\
\text { Control } \\
\text { Systems }\end{array}$} & \multicolumn{3}{|c|}{ Intellectual Capital } \\
\hline & $\mathrm{HC}$ & $\mathrm{SC}$ & $\mathrm{RC}$ \\
\hline \multicolumn{4}{|c|}{ Simons' Levers of Control } \\
\hline $\begin{array}{l}\text { Belief sys- } \\
\text { tem/core } \\
\text { values }\end{array}$ & Attitude & $\begin{array}{l}\text { Organi- } \\
\text { sational } \\
\text { culture; } \\
\text { Recogni- } \\
\text { tion, eval- } \\
\text { uation and } \\
\text { appraisal } \\
\text { systems; } \\
\text { Information }\end{array}$ & \\
\hline $\begin{array}{l}\text { Boundary } \\
\text { systems/ } \\
\text { risks to be } \\
\text { avoided }\end{array}$ & $\begin{array}{l}\text { Knowledge } \\
\text { hiding; } \\
\text { Deviant } \\
\text { behaviour }\end{array}$ & $\begin{array}{l}\text { Poor organ- } \\
\text { isational } \\
\text { culture }\end{array}$ & $\begin{array}{l}\text { Negative } \\
\text { image }\end{array}$ \\
\hline $\begin{array}{l}\text { Diagnostic } \\
\text { control } \\
\text { systems/ } \\
\text { critical per- } \\
\text { formance } \\
\text { variables }\end{array}$ & $\begin{array}{l}\text { Competence; } \\
\text { Personal } \\
\text { attitude, } \\
\text { Skills, } \\
\text { Knowledge, } \\
\text { Experience, } \\
\text { Motivation }\end{array}$ & $\begin{array}{l}\text { Organisa- } \\
\text { tional struc- } \\
\text { tures; } \\
\text { Organi- } \\
\text { sational } \\
\text { culture; } \\
\text { Recogni- } \\
\text { tion, eval- } \\
\text { uation and } \\
\text { appraisal } \\
\text { systems }\end{array}$ & $\begin{array}{l}\text { Brand, } \\
\text { Image, } \\
\text { Social } \\
\text { reputa- } \\
\text { tion; } \\
\text { Clients; } \\
\text { Suppliers; } \\
\text { Competi- } \\
\text { tors }\end{array}$ \\
\hline $\begin{array}{l}\text { Interactive } \\
\text { control } \\
\text { systems/ } \\
\text { strategic } \\
\text { uncertain- } \\
\text { ties }\end{array}$ & $\begin{array}{l}\text { Former expe- } \\
\text { rience; } \\
\text { Attitude; } \\
\text { Knowledge; } \\
\text { Skills; } \\
\text { Personality }\end{array}$ & Information & $\begin{array}{l}\text { Brand, } \\
\text { Image, } \\
\text { Social } \\
\text { reputa- } \\
\text { tion; Cus- } \\
\text { tomers; } \\
\text { Suppliers; } \\
\text { Competi- } \\
\text { tors }\end{array}$ \\
\hline
\end{tabular}

Provided it has a positive image value is generated, but if it has a negative image (for one reason or another) then it leads to value loss. In a similar fashion a firm can benefit from the knowledge and skills of its human capital, but also can be harmed by absence of knowledge and skills. So, in a nutshell, Boundary system can be considered in view of the negative aspect of intangibles (Table 2).

In accordance with those thoughts in earlier research other authors (Merchant, 1982) consider management control as a process of controlling staff behaviour. On the one hand, managers use it to prevent employees from deviant behaviour, which is not in compliance with the goals of the firm. On the other hand, it could help to prevent employees from poor performance of their tasks. On the basis of the aforesaid management control can be seen from a different perspective as it refers not only to the output, but also to the intangibles.

One of the most significant contributions of Simons' framework to the concept of management control systems is related to the fact that he succeeds in putting together the successful strategy performance and suitable control mechanism that could be used to implement strategy. For the purpose of achieving reliable (reasonable) control of the strategy he develops four levers of control. In order to be able to fulfill their function these levers of control should be used together, since they are mutually related and complement one another. They are meant to make managers of successful firms always search how to achieve both high degree of creativity and innovations and at the same time high level of control.

\subsection{Balanced scorecard}

As mentioned above one of the key roles of MCS is to provide a reliable strategy performance measurement system. One of the most commonly applied tools for this purpose in recent decades has been Kaplan and Norton's (1992) Balanced Scorecard (BSc), aimed at linking the firm's objectives and strategy execution. BSc's main advantage is that it links not only strategy to performance, but does it from four different perspectives: financial; customer; innovation and learning, and internal processes. In essence $\mathrm{BSc}$ is about turning the company's vision, mission and strategy into objectives and key performance indicators based on these four perspectives.

Although initially BSc was meant to be applied as a measurement system for nonfinancial values, according to Roos et al. (2005) the model can be applied also to: 
- Clarify the strategy and unify the organisation around it.

- Communicate the strategy to the company.

- Harmonise objectives of units and individuals.

- Link strategic objectives to long-term goals and yearly budgets.

- Identify and harmonize strategic alternatives.

- Carry out periodical and systematic strategic analyses.

Despite its popularity BSc is subject to a lot of critique in management literature. One of the reasons is due to the fact that it was used differently than intended by its creator, which in practice resulted in that senior managers selected the measures and weights used in performance evaluation (Ittner et al., 2003; Berry et al., 2009). This has led to overemphasis of financial measures and little attention to future performance measures that did not support desired results.

Though the idea behind the concept of BSc is strategically relevant, revolutionary and forward looking, its application in practice has led to a lot of deviation and inconsistency from the original idea.

"It was often unclear what organisations were using when they said that they have adopted a balanced scorecard." (Ax \& Bjørnenak, 2005)

However, its authors believe that BSc and strategy map frameworks can benefit from the application of IC components as part of the measurement system (Table 3 ).

Kaplan and Norton $(1992,2004)$ deserve recognition as they are among the first scholars who take into consideration the impact of intangibles on the value creation process, and recoqnise it as a main factor for successful strategy performance. Nevertheless, they have been criticized for twisting the definition of intangibles. Marr and Adams (2004) rightfully draw attention to the fact that in their book Strategy Maps, where Kaplan and Norton (2004) provide a practical framework to illustrate how strategy links intangible assets to value creating processes, they redefine intangible assets by organising them in the categories: human capital, information capital and organisation capital. Marr and Adams (2004) describe these discrepancies between the broadly accepted definition as "similar ideas, unallied concepts". The arguments against this new definition are based on the premise that it is inaccurate and misleading for a number of reasons. First of all, it remains unclear what is the need to redefine the concept of IC.
Table 3. Ballanced Scorecard IC-based performance indicators (source: authors)

\begin{tabular}{|c|c|c|c|}
\hline \multirow{2}{*}{$\begin{array}{c}\text { Manage- } \\
\text { ment } \\
\text { Control } \\
\text { Systems }\end{array}$} & \multicolumn{3}{|c|}{ Intellectual Capital } \\
\hline & $\mathrm{HC}$ & $\mathrm{SC}$ & $\mathrm{RC}$ \\
\hline \multicolumn{4}{|c|}{ Balanced Scorecard } \\
\hline $\begin{array}{l}\text { Financial } \\
\text { Perspective }\end{array}$ & - & - & - \\
\hline $\begin{array}{l}\text { Customer } \\
\text { Perspective }\end{array}$ & - & - & $\begin{array}{l}\text { Brand, } \\
\text { Image, } \\
\text { Social } \\
\text { reputation; } \\
\text { Customers; } \\
\text { Suppliers; } \\
\text { Competi- } \\
\text { tors }\end{array}$ \\
\hline $\begin{array}{l}\text { Internal } \\
\text { Business } \\
\text { Processes } \\
\text { Perspective }\end{array}$ & - & $\begin{array}{l}\text { Organi- } \\
\text { sational } \\
\text { structures; } \\
\text { Organi- } \\
\text { sational } \\
\text { culture; } \\
\text { Recogni- } \\
\text { tion, eval- } \\
\text { uation and } \\
\text { appraisal } \\
\text { systems }\end{array}$ & - \\
\hline $\begin{array}{l}\text { Learning } \\
\text { and Growth } \\
\text { Perspective }\end{array}$ & $\begin{array}{l}\text { Competence; } \\
\text { Personal } \\
\text { attitude, } \\
\text { Skills, } \\
\text { Knowledge, } \\
\text { Experience }\end{array}$ & - & - \\
\hline
\end{tabular}

This can be considered to be a lack of acknowledgement of the previous body of research on the topic of intangible assets. Secondly, in their definition of Informational Capital Kaplan and Norton include tangible assets, such as central servers and communication network. Last but not least in their definition they exclude Relational Capital from the elements of IC. In their Customer Perspective, they take into consideration relations with customers but in a completely different manner. Thus, they totally neglect the accepted definition of IC (Meritum, 2002) without justified reason.

\subsection{Performance management and control framework}

The performance and management control framework (PMC) developed by Otley (1999) and Ferreyra and Otley (2005) builds on Simons' Levers of 
Control (1995) and is aimed at aiding middle level management with 12-questions. This framework is open to further development. Its questions try to cover all aspects of performance and management process. Its main limitation is that the questions are far too long and general. Though, it might be useful on operational level to ask these questions, for the sake of clarity and practicality they need to be classified and structured under overarching themes.

As Ferreira and Otley (2005) rightfully point out one of the most important features of the control systems observed lie in the strength and coherence of the links between different components.

“...it appears more important how particular control tools are used by an organisation than what tools are employed in determining whether they can be categorised as part of a particular level of control." (Ferreira \& Otley, 2005, p. 27)

Table 4. MCS IC-based performance indicators (source: authors)

\begin{tabular}{|c|c|c|c|}
\hline \multirow{2}{*}{$\begin{array}{c}\text { Management } \\
\text { Control } \\
\text { Systems }\end{array}$} & \multicolumn{3}{|c|}{ Intellectual Capital } \\
\hline & $\mathrm{HC}$ & $\mathrm{SC}$ & $\mathrm{RC}$ \\
\hline \multicolumn{4}{|c|}{ Performance management and control framework } \\
\hline Vision and mission & - & $\begin{array}{l}\text { Organisational } \\
\text { structure; Organi- } \\
\text { sational culture; } \\
\text { Management sys- } \\
\text { tems }\end{array}$ & - \\
\hline $\begin{array}{l}\text { Key success fac- } \\
\text { tors }\end{array}$ & - & - & - \\
\hline $\begin{array}{l}\text { Strategies and } \\
\text { plans }\end{array}$ & - & $\begin{array}{l}\text { Organisational } \\
\text { structure }\end{array}$ & - \\
\hline $\begin{array}{l}\text { Key performance } \\
\text { measurement }\end{array}$ & - & - & - \\
\hline Target settings & - & - & - \\
\hline $\begin{array}{l}\text { Performance eval- } \\
\text { uation }\end{array}$ & - & $\begin{array}{l}\text { Evaluation and } \\
\text { appraisal systems }\end{array}$ & - \\
\hline Reward system & - & $\begin{array}{l}\text { Evaluation and } \\
\text { appraisal systems }\end{array}$ & - \\
\hline $\begin{array}{l}\text { Organisational } \\
\text { structure }\end{array}$ & - & $\begin{array}{l}\text { Organisational } \\
\text { structures }\end{array}$ & - \\
\hline Information flows & - & Information & - \\
\hline $\begin{array}{l}\text { Use of PMC sys- } \\
\text { tem }\end{array}$ & - & - & - \\
\hline $\begin{array}{l}\text { Change dynamics } \\
\text { in PMC }\end{array}$ & - & - & - \\
\hline $\begin{array}{l}\text { Links between the } \\
\text { components }\end{array}$ & - & - & - \\
\hline
\end{tabular}

Nevertheless, at this stage the theoretical framework they offer is far too general and vague. Although it treats issues relevant and important to strategic management it lacks systematic representation. The questions asked are far too long and formulated very broadly, they lack focus. Further, it is unclear who in the firm is supposed to answer these questions.

Following the approach in the previous two cases we try to compare Performance Management and Control Framework and analyse how IC elements support its questions (Table 4).

As it becomes evident it is only some elements of Structural capital that are considered. In practice the Performance Management and Control Framework of Ferreira and Otley (2005) does not target intangibles and their impact on value creation, performance and strategy implementation.

The comparative analysis made between the PMC and IC shows that in its nature PMC is an attempt for another complete investigation of Structural capital elements, which is just one of the components of IC. Contrary to the above analysed Simons' levers of control and BSc, whose main advantage is that they take into consideration the impact of intangibles as factors of significant importance to strategic management and strategy implementation, here the idea of intangibles is omitted.

\section{Discussion and conclusion}

Management control is closely related to the processes of formulation of the objectives and strategy planning. Based on the analysis made above, authors come to the conclusion that the frameworks of management control systems acknowledge the significance of intangibles represented by intellectual capital. Therefore, it can be considered that scholars working in the field of management control systems, realise the strategical importance of IC and try to monitor and measure the impact it has on company performance and strategic goals achievement. Bearing in mind the fact that as a concept management control goes beyond the limits of control as a function of management, and includes fields that are different from finance and accounting, gives the authors grounds to search for relationships and opportunities for improving existing MCS. One of the reasons why until now there is no unanimous MCS where elements of IC are clearly defined is due to the fact they are hard to be formalised and parameterised. Nevertheless, it is worth acknowledging that IC-based MCS are applicable in firms from all 
industries and sizes. They can aid management to receive a more informative feedback and enable the process of taking more accurate measures.

Building on the conceptual frameworks of Simons' Levers of Control and BSs, where, in one way or another, intangibles are considered, the authors propose a conceptual framework where, based on comparison, they suggest how IC elements can be embedded in these MCS so that they can become a part of the strategy perfprmance control.

As a result of the comparative analysis made the authors come to the conclusion that the Diagnostic Control System of Simons' Levers of Control is most suitable to be adapted to the elements of IC, while in the Boundary System the possibility to implement intangibles is much less obvious. However, it is exactly in the Boundary System of Simons' Levers of Control where future research questions could be explored. It is the authors' belief that intangibles can be studied not only from their positive side, but also the possibility of negative impact of intangibles on strategy performance is worth investigating. This view is based on the premise that the Boundary System is meant to foster creativity and opportunity seeking by outlining the boundaries and explicitly noting what is not to be done. Regarding the other two systems there is moderate compatibility. However, this does not exclude the possibilities for further, more in-depth analysis and search for solutions in order to include IC elements in MCS. Organisational culture that is supported by a Belief System, as well as the relationships with various stakeholders supported by an Interactive Control System are of significant importance for strategy performance and goals achievement. This justifies further research in this direction, which will allow for their monitoring and control.

Though tightly related, the definition of intangibles used in BSc is different from the more widely accepted one (Meritum, 2002), which rightfully is one of its main critiques. Nevertheless, the authors believe that certain elements of IC can be embedded in BSc. In a way BSc might turn out to be an even more reliable framework for MCS as BSc contain a financial perspective, which is often mentioned as one of the main limitations of Simons' Levers of Control. All other three perspectives of BSc can be upgraded with the elements of IC.

Regarding PMC, the possibility for their further improvement based on IC elements is limited. The authors believe this is due to the fact that the conceptual framework is represented through 12 questions which are very broad and general.
The research findings from the present paper are a result of comparative analysis made between the widely applied Simons' Levers of Control, BSc, PMC and the framework of IC accepted in Meritum project (2002). As a result, it was concluded that the three constituent elements of IC can be applied as an integral part of MCS performance indicators. Firms applying this approach will be able to broaden scope of their MCS and take into consideration the impact of intangibles on value creation.

The implications from this study can contribute to the managerial decision making process and facilitate management in the achievement of company goals as a result of acknowledging and measuring the impact of intangibles. We also consider that there are opportunities for further research in the crossing field between MCS and IC.

The limitations of present study are due to the fact that intangibles are hard to be formalised and quantified. However, the IC-based MCS framework sets foundations for a very useful and practical approach to management control.

\section{Acknowledgement}

This work was supported by the R\&D sector of the Technical University of Sofia.

\section{References}

Anthony, R. N. (1965). Planning and control systems: A framework for analysis. Graduate School of Business Administration, Harvard University Press, Boston, MA.

Anthony, R. V., \& Govindarajan, V. (2007). Management control systems (12th ed.). McGraw-Hill/Irwin.

Ax, C., \& Bjørnenak, T. (2005). Bundling and diffusion of management accounting innovations - the case of the balanced scorecard in Sweden. Management Accounting Research, 1-20. https://doi.org/10.1016/j.mar.2004.12.002

Bedford, D., Malmi, T., \& Sandelin, M. (2016). Management control effectiveness and strategy: An empirical analysis of packages and systems. Accounting, Organisations and Society, 51, 12-28. https://doi.org/10.1016/j.aos.2016.04.002

Berry, A. J., Coad, A. F., Harris, E. P., Otley, D. T., \& Stringer, C. (2009). Emerging themes in management control: A review of recent literature. The British Accounting Review, 41, 2-20. https://doi.org/10.1016/j.bar.2008.09.001

Claver-Cortes, E., Lopez-Gamero, M. D., Molina-Azorin, J. F., \& Zaragoza-Saez, P. D. C. (2007). Intellectual and environmental capital. Journal of Intellectual Capital, 8(1), 171-182. https://doi.org/10.1108/14691930710715123 
Collier, P. (2005). Entrepreneurial control and the construction of a relevant accounting. Management Accounting Research, 16, 321-339. https://doi.org/10.1016/j.mar.2005.06.007

Galabova, L., \& Ahonen, G. (2011). Is intellectual capital-based strategy market-based or resource-based?: on sustainable strategy in a knowledge-based economy. Journal of Human Resource Costing \& Accounting, 15(4), 313-327. https://doi.org/10.1108/14013381111197243

Ferreira, A., \& Otley, D. (2005). The design and use of management control systems: An extended framework for analysis. Social Science Research Network. https://doi.org/10.2139/ssrn.682984

Ittner, C. D., Larcker, D. F., \& Meyer, M. W. (2003). Subjectivity and the weighting of performance measures: Evidence from a balanced scorecard. The Accounting Review, 78(3), 725-759.

https://doi.org/10.2308/accr.2003.78.3.725

Johanson, U., Ahonen, G., \& Roslender, R. (2007). Work health and management control. Thomson Fakta AB.

Kaplan, R. S., \& Norton, D. P. (1992). The balanced scorecard - measures that drive performance. Harvard Business Review, 71-79.

Kaplan, R. S., \& Norton, D. P. (2004). Strateg maps: Converting intangible assets into tangible outcomes. Harvard Business School Press.

Langfield-Smith, K. (1997). Management control systems and strategy: A critical review. Accounting, Organisations and Society, 22(2), 207-232. https://doi.org/10.1016/S0361-3682(95)00040-2

Lowe, E. A. (1971). On the idea of management control system: Integrating accounting and management control. Journal of Management Studies, 8(1), $1-12$.

https://doi.org/10.1111/j.1467-6486.1971.tb00833.x
Marr, B., \& Adams, C. (2004). The Balanced Scorecard and intangible assets: similar ideas, unaligned concepts. Measuring Business Excellence, 8(3), 18-27. https://doi.org/10.1108/13683040410555582

Merchant, K. (1982). The control function of management. Sloan Management Review, 23(4), 43-55.

Meritum. (2002). Guidelines for managing and reporting on intangibles (Intellectual Capital Report). EU (TSER).

Otley, D. T. (1999). Performance management: a framework for management control systems research. Management Accounting Research, 10, 353-382. https://doi.org/10.1006/mare.1999.0115

Otley, D. T., Broadbent, J. M., \& Berry, A. J. (1995). Research in management control: an overview of its development. British Journal of Management, 6, S31-S34.

https://doi.org/10.1111/j.1467-8551.1995.tb00136.x

Parker, L. D. (1986). Developing control concepts in the $20^{\text {th }}$ century. Garland.

Roos, G., Pike, S., \& Fernström, L. (2005). Managing intellectual capital in practice. Butterworth-Heinemann, Elsevier.

Simon, R. (1995). Levers of Control: How managers use innovative control systems to drive strategic renewal. Harvard Business School Press.

Susdarsanam, S., Sorwar, G., \& Marr, B. (2006). Real options and the impact of intellectual capital on corporate value. Journal of Intellectual Capital, 7(3), 291-308.

https://doi.org/10.1108/14691930610681410

Sveiby, K. E. (1997). The new organizational wealth: managing and measuring knowledge-based assets. Berrett-Koehler. 